\title{
Porównanie modeli prędkości obliczonych z wykorzystaniem różnych wariantów prędkości i algorytmów na profilu sejsmicznym 2D na potrzeby migracji czasowej po składaniu
}

\section{Comparison of velocity models computed using different velocity variants and algorithms on a 2D seismic profile for poststack time migration}

\author{
Łukasz Bajewski, Aleksander Wilk, Andrzej Urbaniec \\ Instytut Nafty i Gazu - Państwowy Instytut Badawczy
}

\begin{abstract}
STRESZCZENIE: W niniejszym artykule zaprezentowano sposób konstrukcji pola prędkości do migracji czasowej po składaniu dla sejsmiki 2D obliczonego na bazie prędkości interwałowych w otworach wiertniczych i interpretacji strukturalnej, a także wyniki migracji czasowej po składaniu z wykorzystaniem tego rozwiązania. Opracowane zostały trzy modele pól prędkości. Modele te różni sposób przestrzennej interpolacji i ekstrapolacji w przyjętym gridzie obliczeniowym w domenie głębokości, który został stworzony na bazie interpretacji strukturalnej profili sejsmicznych 2D. Zastosowano trzy sposoby interpolacji i ekstrapolacji: wg rozkładu Gaussa, kriging oraz moving average. Przestrzennej dystrybucji prędkości interwałowych w otworach wiertniczych dokonano przy zastosowaniu programu Petrel firmy Schlumberger. Z obliczonych przestrzennych modeli prędkości interwałowych na potrzeby migracji czasowej po składaniu zostały wyekstrahowane prędkości interwałowe wzdłuż analizowanego profilu sejsmicznego, które po konwersji z domeny głębokości do domeny czasu zostały użyte do migracji czasowej po składaniu. Dla porównania do tego samego profilu sejsmicznego zastosowano procedurę migracji czasowej po składaniu w oparciu o prędkości składania otrzymane w procesie przetwarzania danych sejsmicznych w wyniku analiz prędkości. Pole obliczone na bazie prędkości interwałowych i interpretacji strukturalnej zostało wykorzystane do czasowej migracji po składaniu obliczonej algorytmem Implicit FD Time Migration (różnic skończonych), natomiast pole prędkości składania zostało użyte do czasowej migracji po składaniu obliczonej algorytmami Stolta i Kirchhoffa zgodnie z uwarunkowaniami technicznymi poprawnego działania tych algorytmów do migracji. Dla wszystkich pól prędkości zostały zastosowane ich wartości procentowe w wybranych zakresach: 60\%, 100\% i 140\%. Wprowadzenie elementu kierunkowej zmienności prędkości, wynikającej z przestrzennej dystrybucji prędkości interwałowych w otworach, do pola prędkości użytego do migracji czasowej po składaniu pozwoliło na uzyskanie lepszego obrazu sejsmicznego w stosunku do obrazu otrzymanego w wyniku zastosowania prędkości składania. Najbardziej wiarygodny obraz sejsmiczny uzyskany w wyniku migracji czasowej po składaniu otrzymano przy zastosowaniu pola prędkości obliczonego na bazie prędkości interwałowych z rozkładem Gaussa, przy użyciu algorytmu różnic skończonych i wartości $60 \%$ pola prędkości.
\end{abstract}

Słowa kluczowe: model prędkości, prędkości interwałowe, prędkości składania, migracja, sekcja sejsmiczna.

ABSTRACT: This article presents a construction method of the velocity field for poststack time migration for 2D seismic calculated on the basis of interval velocities in boreholes and structural interpretation, as well as the results of poststack time migration based on this solution. Three velocity field models have been developed. The models used differ in the way of spatial interpolation and extrapolation in the adopted calculation grid in the depth domain, which was created on the basis of a structural interpretation of 2D seismic profiles. Three methods of interpolation and extrapolation were used: Gaussian distribution, kriging and moving average. The spatial distribution of the interval velocities in the boreholes was made using the Petrel software by Schlumberger. The interval velocities along the analyzed seismic profile were extracted from the computed spatial interval velocity models, and after conversion from the depth to the time domain, they were used for the poststack time migration. For comparison, poststack time migration was calculated for the same seismic profile based on the stacking velocities obtained in the seismic processing data as a result of velocity analyzes. The velocity field calculated on the basis of interval velocities and structural interpretation was used for the poststack time migration procedure performed with the Implicit FD Time Migration algorithm (finite difference), while the stacking velocities were used for the poststack time migration procedure performed with the Stolt and Kirchhoff algorithms in accordance with the technical conditions of

Autor do korespondencji: Ł. Bajewski, e-mail: lukasz.bajewski@inig.pl

Artykuł nadesłano do Redakcji: 08.01.2021 r. Zatwierdzono do druku: 02.07.2021 r. 
correct operation of these algorithms. The selected percentage ranges of $60 \%, 100 \%$, and $140 \%$ have been used for all velocity fields. Application of the element of directional velocity variation resulting from the spatial distribution of interval velocities in the boreholes to the velocity field for the poststack time migration allowed to obtain a better seismic image in relation to the one obtained as a result of applying the stacking velocities. The most reliable seismic image after poststack time migration was obtained for the velocity field calculated on the basis of the interval velocities with Gaussian distribution, using the finite difference algorithm with 60 percent value of the velocity field.

Key words: velocity model, interval velocities, stacking velocities, migration, seismic section.

\section{Wstęp}

Podstawowym celem migracji czasowej po składaniu jest przemieszczenie refleksów sejsmicznych pochodzących od granic odbijających, otrzymanych w wyniku sumowania tras sejsmicznych, do ich rzeczywistego położenia, a tym samym uzyskanie wiarygodnego obrazu strukturalnego. Istotnym elementem migracji czasowej po składaniu jest również otrzymanie większej ciągłości i dynamiki refleksów. Migrację czasową po składaniu realizuje się w oparciu o pole prędkości, które stanowi podstawowy parametr migracji. Migracja oparta na prawidłowym rozpoznaniu rozkładu prędkości znacznie poprawia rozdzielczość przestrzenną, a zwłaszcza rozdzielczość poziomą analizowanego obrazu sejsmicznego (Yilmaz, 2001). Aby w sposób poprawny odtworzyć obraz strukturalny na przekroju sejsmicznym, konieczne jest prawidłowe rozpoznanie rozkładu prędkości. Rutyna przemysłowa bazuje głównie na polu prędkości uzyskanym w procesie przetwarzania danych sejsmicznych, tzw. prędkości składania, nazywanych również prędkościami RMS. Prędkości te są otrzymywane w procesie analiz prędkości, na których bazuje proces składania tras według wspólnego punktu środkowego (CMP). Uzyskane w ten sposób pole prędkości obarczone jest błędami wynikającymi głównie z interpolacji (analiza odbywa się z przyjętym krokiem CMP), a także z niedokładności samej metody (szczególnie dla dalekich offsetów). Powoduje to zniekształcenia na zmigrowanej sekcji sejsmicznej (objawiające się miejscami „przemigrowanymi” i ,niedomigrowanymi"), co z kolei może prowadzić do powstawania błędów w interpretacji modelu geologicznego. Innymi słowy, niewłaściwe określenie prędkości do migracji skutkuje niewłaściwym umiejscowieniem elementów strukturalnych, zarówno w pionie, jak i w poziomie, ich zniekształceniem, a często ich eliminacją bądź generowaniem nieistniejących elementów strukturalnych. Wyjściem z tej sytuacji jest

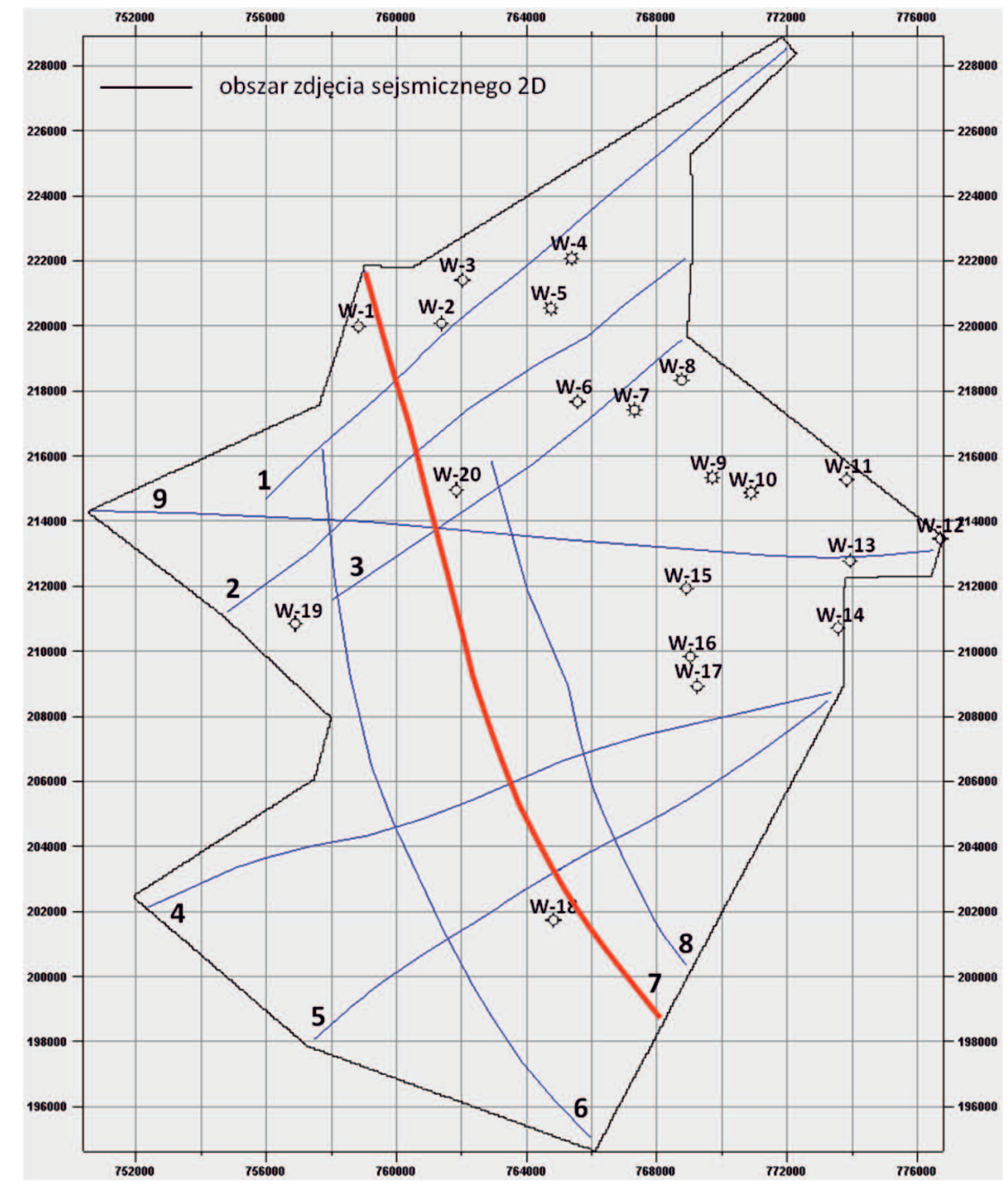

Rys. 1. Lokalizacja profili sejsmicznych $2 \mathrm{D}$ oraz wybranych otworów wiertniczych z pomiarami prędkości interwałowych. Kolorem czerwonym zaznaczono analizowany profil $\mathrm{nr} 7$

Fig. 1. Location of 2D seismic profiles and selected boreholes with interval velocity measurements. The analyzed profile no. 7 is marked in red 
pola prędkości do migracji czasowej po składaniu. Prędkości składania są pozbawione tego elementu, a zatem dostarczają informacji tylko wzdłuż analizowanego profilu.

W tym przypadku realizację przestrzennej dystrybucji prędkości interwałowych w otworach wiertniczych wykonano, wykorzystując rozkład Gaussa, kriging i moving average w przyjętej przestrzeni obliczeniowej przy użyciu oprogramowania Petrel. Przestrzeń obliczeniowa została stworzona na podstawie interpretacji strukturalnej wybranych horyzontów sejsmicznych na profilach 2D (rys. 1, 3).

Wprowadzenie elementu kierunkowej zmienności prędkości do pola prędkości na potrzeby migracji czasowej po składaniu pozwoliło na uzyskanie lepszego obrazu sejsmicznego w stosunku do obrazu otrzymanego w wyniku zastosowania prędkości składania. Uzyskany obraz sejsmiczny manifestuje się lepszą ciągłością i dynamiką refleksów.

Przygotowanie pola prędkości składania otrzymanego na etapie przetwarzania danych sejsmicznych oraz migrację czasową po składaniu przy użyciu algorytmów Kirchhoffa, Stolta i różnic skończonych wykonano w systemie SeisSpace (ProMAX) - Seismic Processing and Analysis
Release 5000.10.0.1. na profilu sejsmicznym 2D nr 7 z rejonu Karpat zewnętrznych (rys. 1).

Nazewnictwo otworów wiertniczych i profili sejsmicznych zostało zakodowane ze względu na konieczność ochrony informacji.

\section{Krótka charakterystyka geologiczna rejonu badań}

Profil sejsmiczny, na którym wykonana została migracja czasowa po składaniu, zlokalizowany jest w brzeżnej części Karpat zewnętrznych, w południowo-wschodniej części Polski (rys. 2). Rejon badań charakteryzuje się dużym stopniem skomplikowania budowy geologicznej, co przekłada się na znaczną trudność w jego odwzorowaniu na sekcjach sejsmicznych.

W obrębie analizowanego rejonu wyróżnić można trzy główne piętra strukturalne. Najniższe piętro stanowi seria anchimetamorficznych skał neoproterozoiku, związanych genetycznie z blokiem małopolskim (rys. 2). Seria ta zalega bezpośrednio w podłożu utworów neogenu, tym samym omawiany obszar jest całkowicie pozbawiony pokrywy osadów

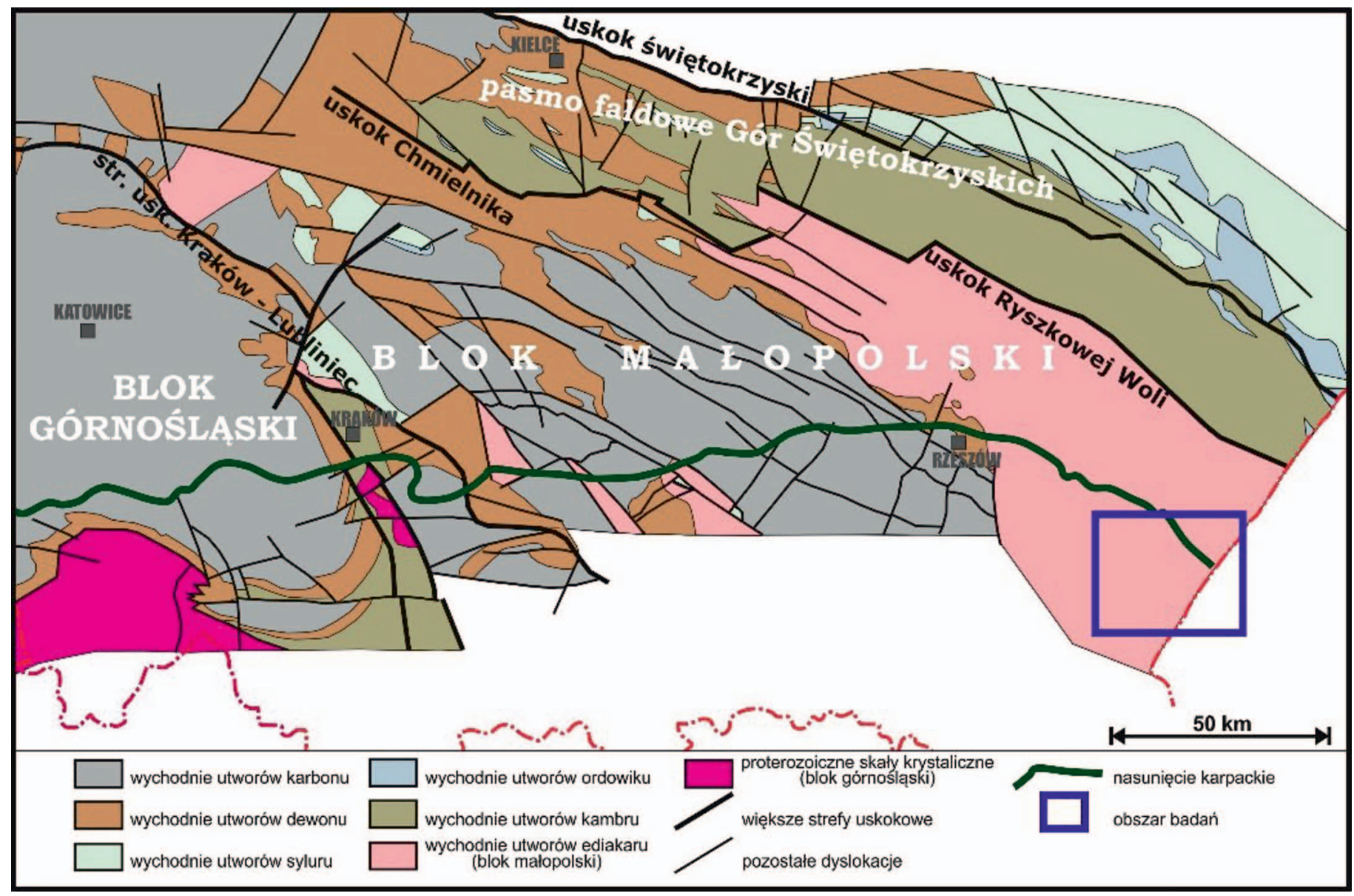

Rys. 2. Lokalizacja obszaru badań na tle głównych jednostek tektonicznych Polski pod pokrywą permsko-mezozoiczną i kenozoiczną (według Żelaźniewicza i in. (2011), częściowo zmienione)

Fig. 2. Location of the study area against the main tectonic units of Poland under the Permian-Mesozoic and Cenozoic cover (according to Żelaźniewicz et al., 2011, partially changed) 
paleozoicznych i mezozoicznych. Środkowe piętro strukturalne w analizowanym rejonie stanowi kompleks osadów klastycznych z wkładkami ewaporatów wieku mioceńskiego, o bardzo dużym zróżnicowaniu miąższościowym (Urbaniec, 2017). Najwyższe piętro strukturalne reprezentują utwory allochtoniczne pokrywy tektonicznej, włączane w obręb trzech dużych jednostek: stebnickiej, borysławsko-pokuckiej i skolskiej. Jedną z najbardziej charakterystycznych cech orogenu fliszowego $\mathrm{w}$ analizowanym rejonie jest intensywne złuskowanie, $\mathrm{z}$ dachówkowym ułożeniem poszczególnych łusek, nasuniętych kolejno na siebie (Kotlarczyk, 1988).

Bardziej szczegółowa budowa geologiczna obszaru badań, obejmująca poszczególne piętra strukturalne analizowanego rejonu wraz z obowiązującymi podziałami litostratygraficznymi dla poszczególnych jednostek, przedstawiona została w poprzednich publikacjach (Urbaniec, 2017; Urbaniec et al., 2017).

\section{Budowa modelu prędkości na potrzeby migracji czasowej po składaniu}

Zagadnienie budowy pola prędkości do czasowej migracji sejsmicznej było wielokrotnie i dyskutowane w literaturze (np. Al-Chalabi, 1994; Al-Chalabi i Rosenkranz, 2002; Wilk et al., 2018). Istnieje wiele opatentowanych rozwiązań tego zagadnienia. Poszczególni autorzy proponują różnorodne metody odnoszące się do niego w zależności od metodyki pomiaru, jak również ilości i jakości danych na potrzeby badań sejsmicznych. Istotnym elementem w budowie pola prędkości jest uwzględnienie niejednorodności ośrodka, przejawiającej się w jego anizotropii. Wpływ anizotropii prędkości na wynik migracji czasowej jest badany od wielu lat (np.: Kostecki i Półchłopek, 1998, 2003, 2013; Tsvankin et al., 2010; Kostecki, 2011; Kostecki i Żuławiński, 2013, 2014, 2015; Kostecki et al., 2013). Kolejną komplikację stanowi fakt, że w metodach sejsmicznych pole prędkości nie jest pojęciem bezwzględnym. Zależy ono zarówno od metodyki pomiaru (badania sejsmiczne, profilowania otworowe, badania laboratoryjne), jak i zastosowania (prędkości składania, prędkości do migracji, prędkości do transformacji czas-głębokość itd.). Również autorzy niniejszego opracowania, w poprzednich pracach zaproponowali sposób na opracowanie pola prędkości do migracji czasowej po składaniu, wykorzystując dane z pomiarów pionowych profilowań sejsmicznych w otworach i interpretację strukturalną (Bajewski et al., 2017; Wilk et al., 2018).

W niniejszym artykule do budowy przestrzennego pola prędkości do migracji czasowej po składaniu zostały wykorzystane prędkości interwałowe $\mathrm{z}$ otworów. Równolegle $\mathrm{z}$ analizami prędkości w procesie przetwarzania zostało opracowane pole prędkości składania.

\section{Konstrukcja modeli prędkości na podstawie dystrybucji prędkości interwałowych}

Do konstrukcji modelu prędkości wybrano wszystkie dostępne otwory (od W-1 do W-20) w obszarze interpretowanego zdjęcia sejsmicznego, które posiadały pomierzone w nich prędkości interwałowe (rys. 1).

Istotny element $\mathrm{w}$ konstrukcji modelu prędkości stanowił sposób rozwiązania dystrybucji prędkości interwałowych,

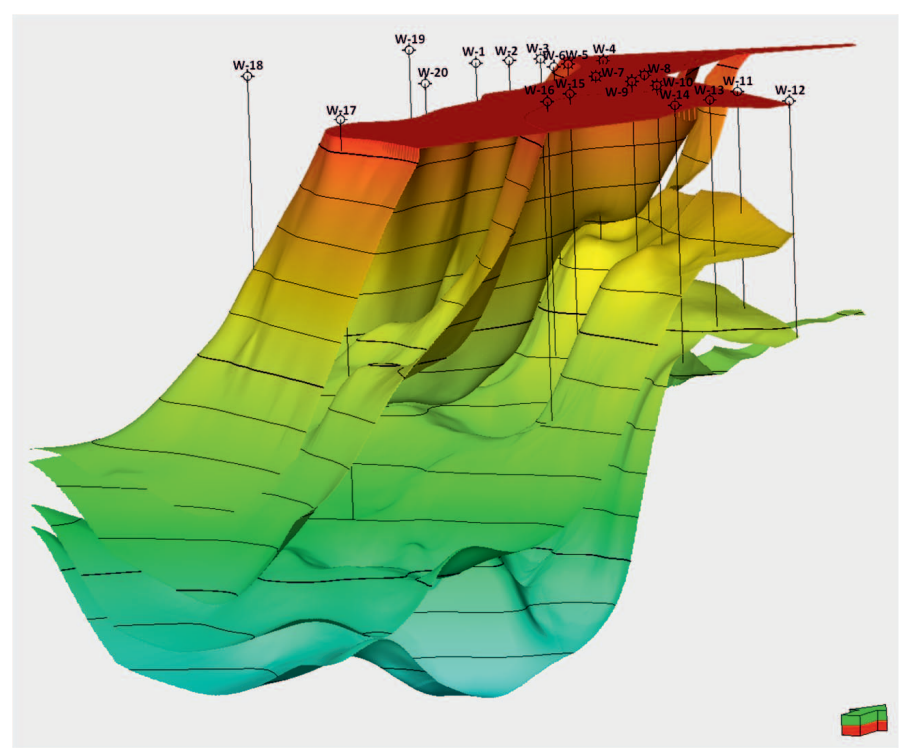

Rys. 3. Interpretacja strukturalna obszaru badań (powierzchni nasunięć) w domenie głębokości

Fig. 3. Structural interpretation of the research area in the depth domain

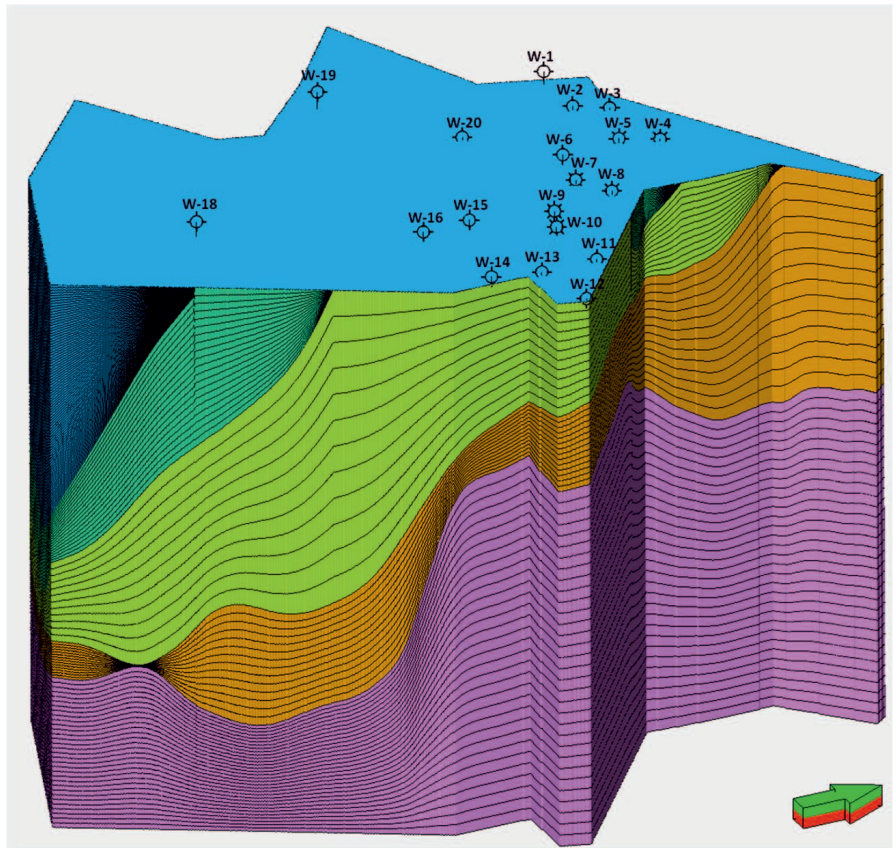

Rys. 4. Grid obliczeniowy powstały na bazie modelu strukturalnego w domenie głębokości

Fig. 4. The computational grid created on the basis of a structural model in the depth domain 
który umożliwiałby najbardziej wiarygodne odtworzenie budowy skomplikowanych ośrodków geologicznych w procesie migracji czasowej. Algorytm realizujący postawione założenia powinien zachować wysoką dokładność rozkładu zmiennych w przypadku ograniczonej ilości lub braku danych.

W celu rozwiązania powyższego zadania na bazie modelu strukturalnego (rys. 3), powstałego w wyniku interpretacji profili sejsmicznych, stworzono grid obliczeniowy w domenie głębokości (rys. 4). Model strukturalny obejmował interpretację powierzchni nasunięć głównych jednostek fliszowych. Grid został podzielony proporcjonalnie na warstwy o średniej miąższości $50 \mathrm{~m}$. W miejscach o dużej miąższości pomiędzy poszczególnymi powierzchniami nasunięć warstwy przekraczały zadany interwał, a w miejscach wyraźnego zmniejszenia miąższości ulegały redukcji (rys. 4).

Prędkości interwałowe w otworach zostały przeskalowane do przyjętego gridu obliczeniowego (rys. 4) i rozdystrybuowane z wykorzystaniem trzech różnych algorytmów w programie Petrel (rys. 5, 6):

- rozkład Gaussa - stochastyczna estymacja parametrów oparta na obliczonych wariogramach $\mathrm{z}$ danych wejściowych;

- kriging - deterministyczna estymacja parametrów oparta na obliczonych wariogramach z danych wejściowych;

- moving average - interpolacja i ekstrapolacja parametrów oparta na metodzie średniej ważonej.

Z powyższych modeli prędkości interwałowych na potrzeby migracji czasowej po składaniu zostały wyekstrahowane prędkości interwałowe wzdłuż analizowanego profilu sejsmicznego nr 7 (rys. 7).

Następnie dokonano ich konwersji z domeny głębokości do domeny czasu w celu realizacji migracji czasowej po składaniu i poddano je optymalizacji. W tym celu przygotowane do migracji obliczone modele prędkości zostały poddane analizie pod względem zakresu uzyskanych wartości prędkości, a następnie poddane iteracyjnemu wygładzaniu. Ostatecznie zweryfikowane i wygładzone pola prędkości zostały przetestowane algorytmami computing grid migracji czasowej po składaniu z użyciem do tego celu zakresów procentowych ich wartości.

\section{Prędkości składania}

Analizy prędkości w procesie przetwarzania danych sejsmicznych przeprowadza się na kolekcjach wspólnego punktu środkowego (CMP) uzyskanych w wyniku przesortowania zarejestrowanych w procesie akwizycji tras sejsmicznych

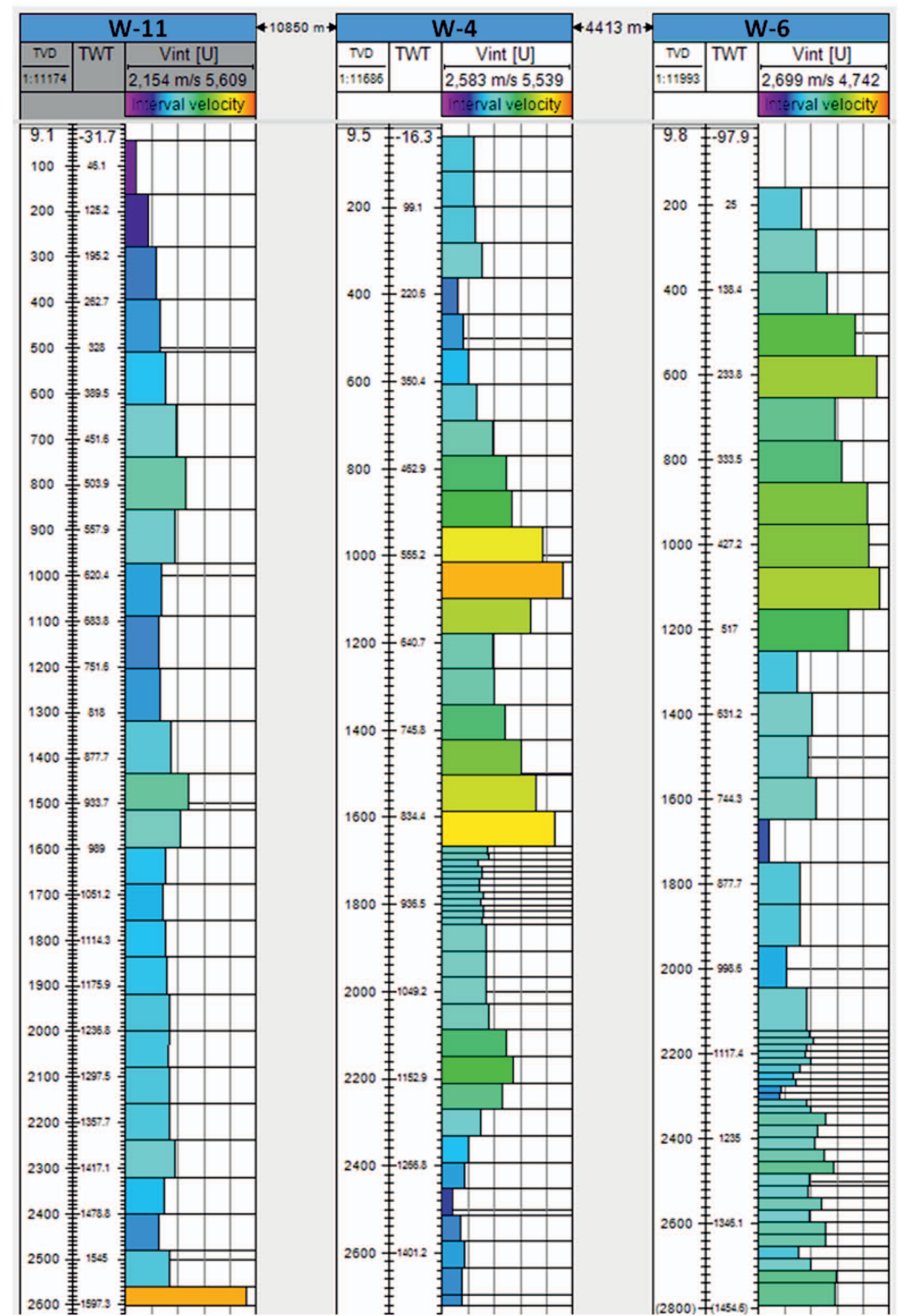

Rys. 5. Przykład przeskalowania prędkości interwałowych w otworach W-11, W-4, W-6 do gridu obliczeniowego

Fig. 5. An example of rescaling the interval velocities in the wells: W-11, W-4, W-6 to the 
a)

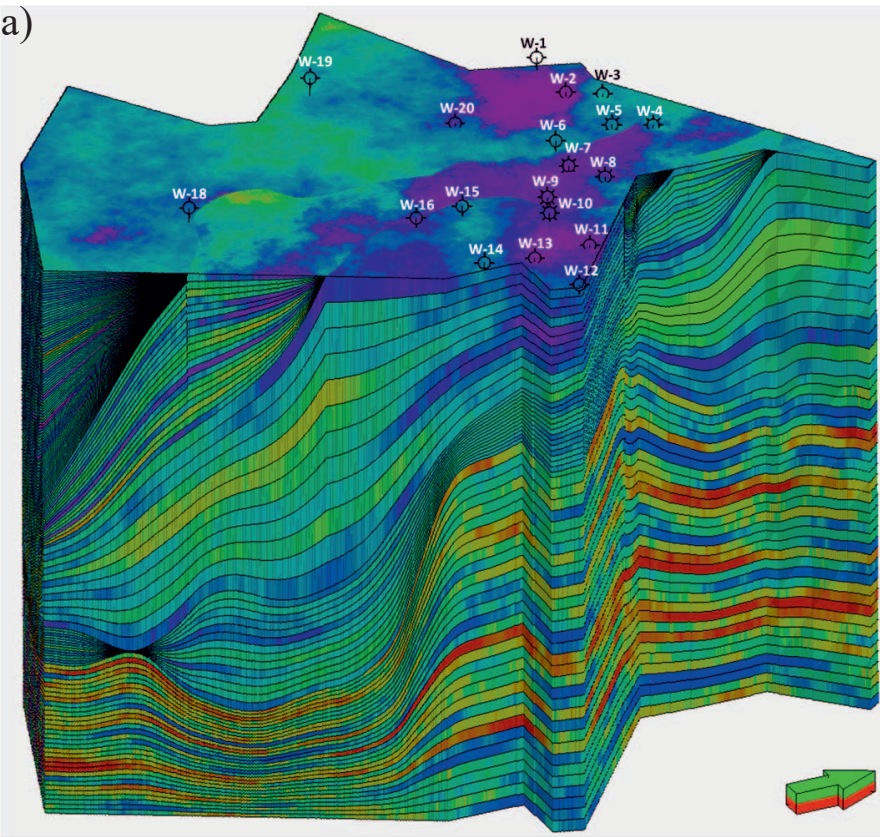

c)

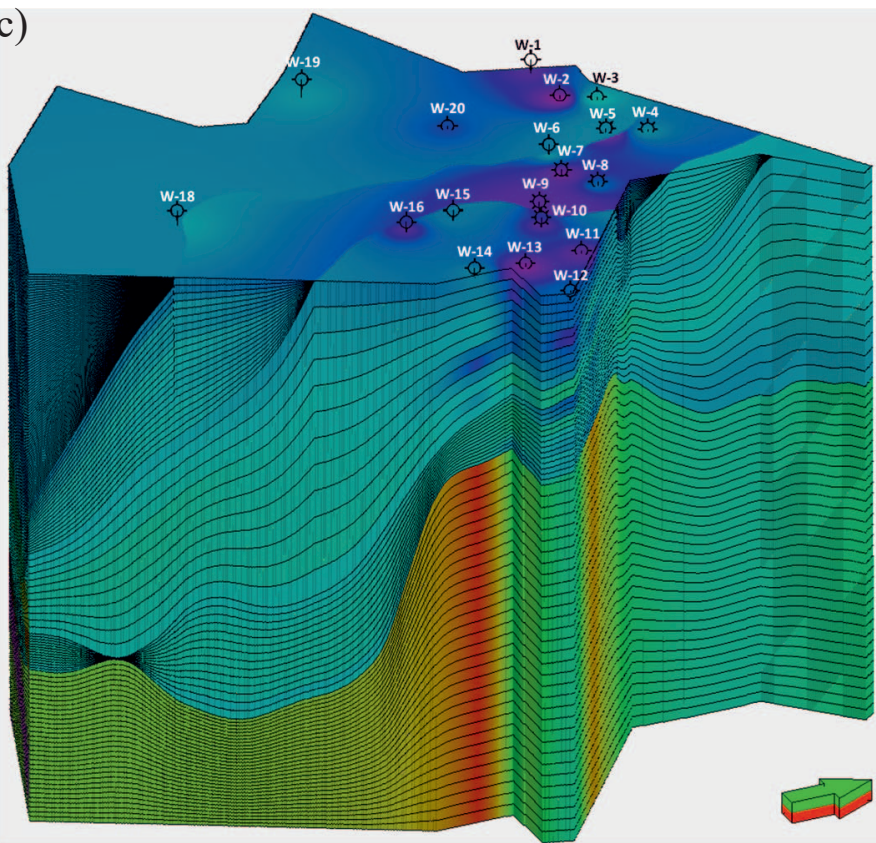

b)

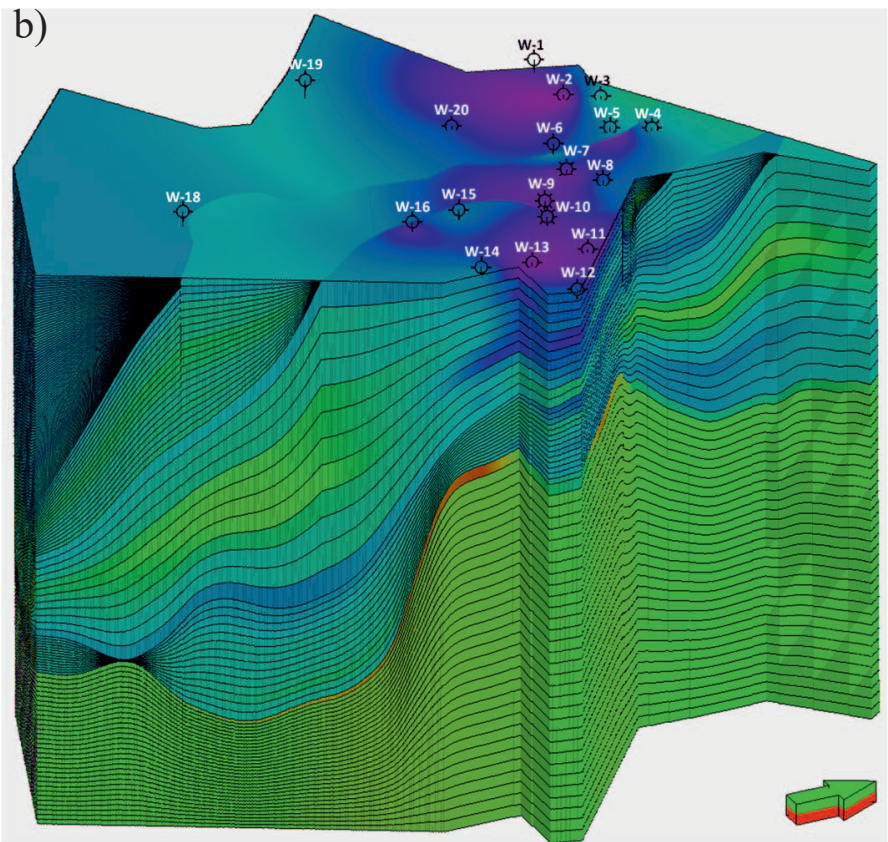

Rys. 6. Przestrzenny rozkład prędkości interwałowych uzyskany:

a) rozkładem Gaussa, b) rozkładem kriging oraz c) rozkładem moving average

Fig. 6. The spatial distribution of interval velocities obtained with: a) the Gaussian distribution, b) the kriging distribution and c) the moving average distribution

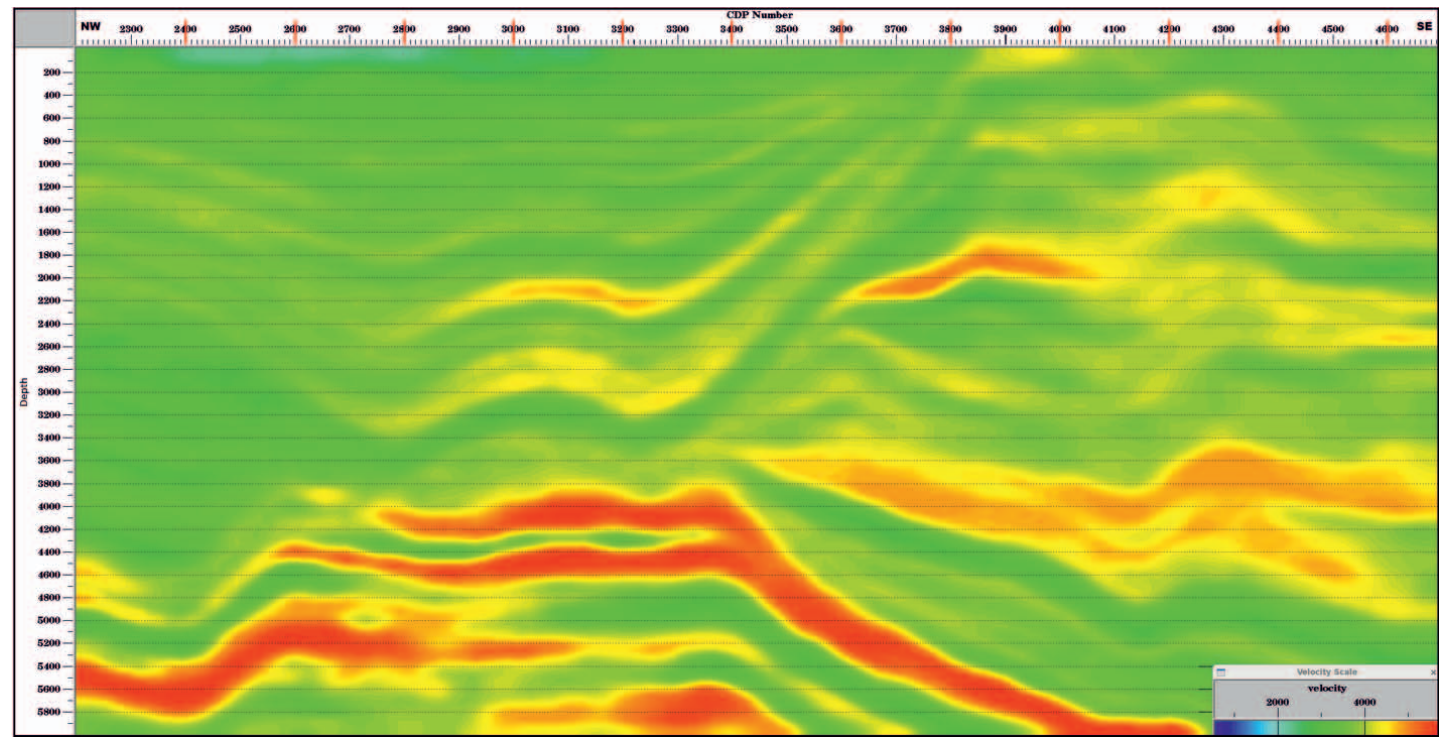

Rys. 7. Rozkład prędkości interwałowych po wygładzaniu uzyskany algorytmem rozkładu Gaussa na profilu sejsmicznym $\mathrm{nr} 7$ w domenie głębokości

Fig. 7. Interval velocity distribution after smoothing, obtained with the Gaussian distribution algorithm on the seismic profile no. 7 in depth domain 
(Sheriff, 2002). Każda pojedyncza trasa sejsmiczna przypisana jest do punktu będącego środkiem pomiędzy punktem strzałowym a punktem odbioru rejestrującym daną trasę. Trasy odpowiadające punktom środkowym o tej samej lokalizacji grupowane są razem, tworząc w ten sposób kolekcje CMP.

Refleksy sejsmiczne pochodzące od granic odbijających na trasach przesortowanych do zbioru wspólnego CMP układają się na krzywej zbliżonej do kształtu hiperboli (rys. 8). Aby wykonać procedurę sumowania wszystkich tras zawartych w kolekcji CMP w celu otrzymania wynikowej trasy, konieczne jest wyprostowanie tej krzywej poprzez aplikację poprawki kinematycznej (NMO) dla każdej trasy kolekcji CMP (rys. 8) (Yilmaz, 2001). Poprawki te obliczane są na bazie prędkości,

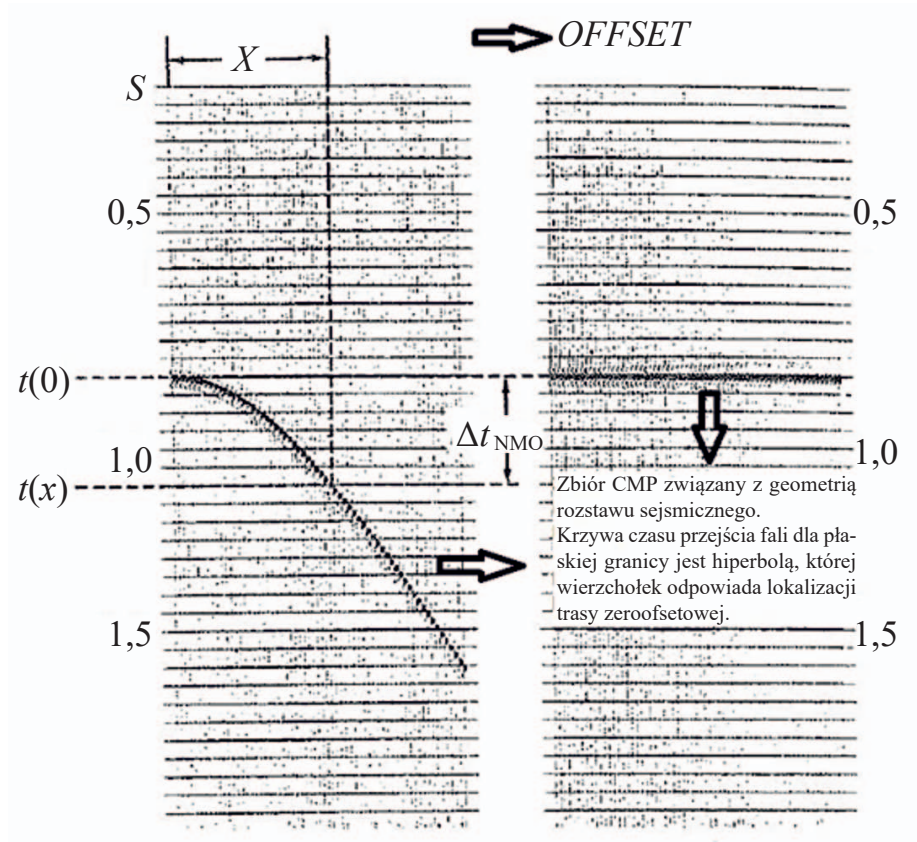

(a)

(b)

Rys. 8. Zasada działania poprawki kinematycznej (Yilmaz, 2001)

Fig. 8. Principle of kinematic correction (Yilmaz, 2001) które otrzymuje się w wyniku ich interaktywnej analizy na kolekcjach CMP w procesie przetwarzania danych sejsmicznych. Cała analiza poprawek kinematycznych wykonywana jest w układzie współrzędnych prędkość-czas z wykorzystaniem do tego celu interaktywnego narzędzia w programach do przetwarzania danych sejmicznych - Semblance (Kasina, 2005). Wartości uzyskanych poprawek są interpolowane pomiędzy analizowanymi punktami CMP, tworząc wynikowe pole prędkości składania. Prawidłowo dobrane wartości prędkości, a tym samym poprawki kinematycznej, zapewniają najwyższy wskaźnik spójności sygnału sejsmicznego (koherencji sygnału) na sekcji sejsmicznej.

Otrzymany w ten sposób model prędkości składania został poddany analizie pod względem zakresu uzyskanych wartości prędkości i poddany iteracyjnemu wygładzaniu (rys. 9). Ostatecznie zweryfikowane i wygładzone pole prędkości zostało przetestowane algorytmami migracji czasowej po składaniu z użyciem do tego celu zakresów procentowych ich wartości.

\section{Wyniki migracji czasowej po składaniu}

Do otrzymanych modeli prędkości zastosowano migrację czasową po składaniu w trzech wariantach opartych na najczęściej stosowanych algorytmach (Sheriff, 2002; Schlumberger, 2020):

- migracji Kirchhoffa;

- migracji Stolta;

- migracji Implicit FD Time Migration (różnic skończonych). Zgodnie z uwarunkowaniami technicznymi poprawnego działania wytypowanych algorytmów do migracji Kirchhoffa oraz Stolta wykorzystano pole prędkości uzyskane z prędkości składania na etapie przetwarzania danych sejsmicznych, natomiast do migracji różnic skończonych - pole prędkości

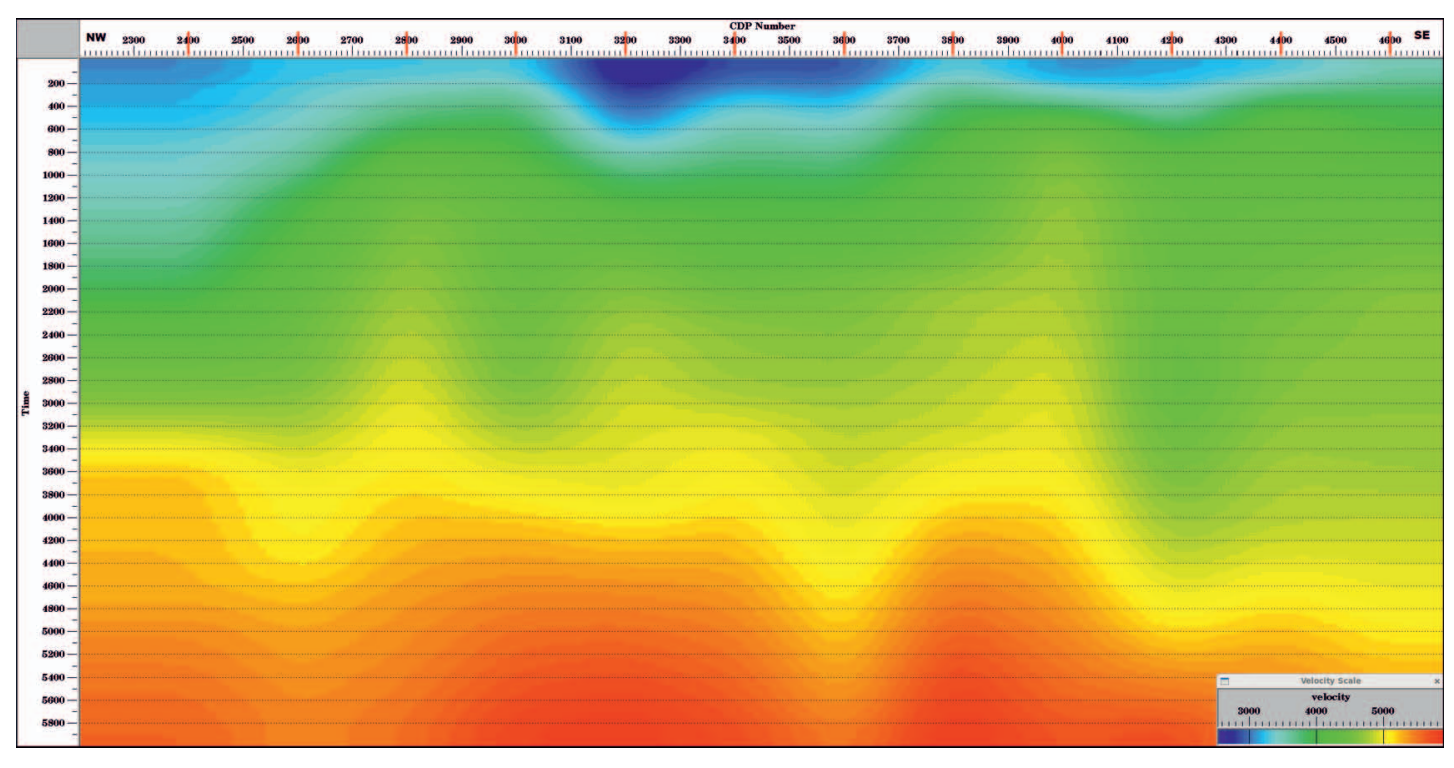

Rys. 9. Rozkład prędkości składania po wygładzaniu uzyskany w wyniku przetwarzania danych sejsmicznych na wytypowanym profilu sejsmicznym nr 7

Fig. 9. Stacking velocity distribution after smoothing, obtained as a result of processing seismic data on the selected seismic section no. 7 
interwałowych otrzymanych z danych otworowych (Promax Reference Manual Contents, 2016; Schlumberger, 2020).

Przeprowadzono szereg testów doboru częstotliwości i apertury migracji w celu uzyskania optymalnych wyników. Testy te zostały wykonane dla wszystkich obliczonych pól prędkości interwałowych (rozkład Gaussa, kriging, moving average), jak również dla pola prędkości składania.

Każdy z trzech algorytmów migracji został przetestowany przy użyciu $60 \%, 100 \%$ i 140\% uzyskanych pól: pola prędkości składania, jak i pól prędkości interwałowych przy zastosowaniu wytypowanego zakresu częstotliwości i apertury migracji.

Na otrzymanych sekcjach sejsmicznych po migracji obrazy strukturalne generalnie są do siebie dosyć podobne pomimo aplikowanych różnych pól prędkości interwałowych, jak i pola prędkości składania, obliczonych z użyciem różnych algorytmów migracji czasowej po składaniu. Migracje wykonane przy użyciu pola prędkości interwałowych różnią się od migracji wykonanych przy użyciu pola prędkości składania, co można wyraźnie zauważyć w części SW profilu w przedziale czasowym $2800-3600 \mathrm{~ms}$ (rys. 15). Wyraźne różnice w obrazie sejsmicznym wynikowych migracji obserwuje się przy szczegółowej analizie obrazu sejsmicznego. Widoczne są zarówno horyzontalne, jak i wertykalne zmiany położenia refleksów sejsmicznych, ich różne kąty nachylenia (szczególnie w zachodniej części omawianego profilu), jak również zmiany w ich ciągłości i dynamice dla wszystkich wariantów migracji. Porównując zapis sejsmiczny pod kątem wartości zastosowań procentowych pól prędkości, można stwierdzić, że przy zastosowaniu $100 \%$ pola prędkości pojawiają się w wielu miejscach ,przemigrowania" (rys. 11, 13, 15), które przy użyciu 140\% pola są już bardzo znaczące. Omawiane powyżej różnice w zapisie sejsmicznym wynikowych migracji zaznaczone zostały w postaci elips na rysunkach 10-15.

Najbardziej wiarygodny pod kątem odwzorowania strukturalnego obraz sejsmiczny, uzyskany po procedurze migracji

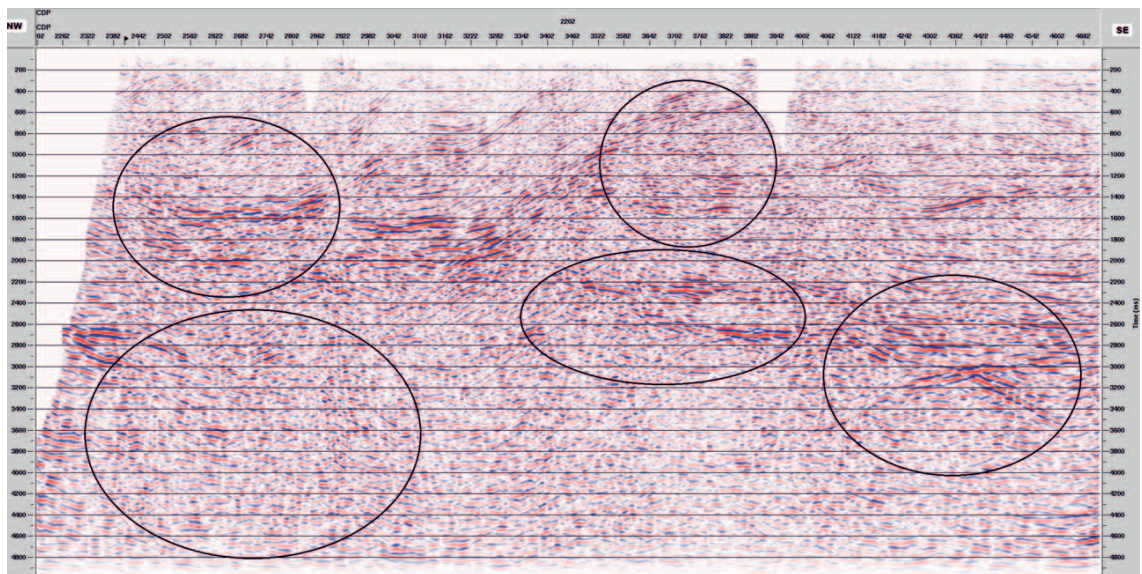

Rys. 10. Migracja czasowa wykonana algorytmem różnic skończonych dla pola prędkości interwałowych obliczonych algorytmem rozkładu Gaussa przy zastosowaniu $60 \%$ wartości pola prędkości

Fig. 10. Poststack time migration calculated with the Implicit FD Time Migration algorithm for the stacking velocity field performed with the Gauss algorithm using $60 \%$ of the velocity field value

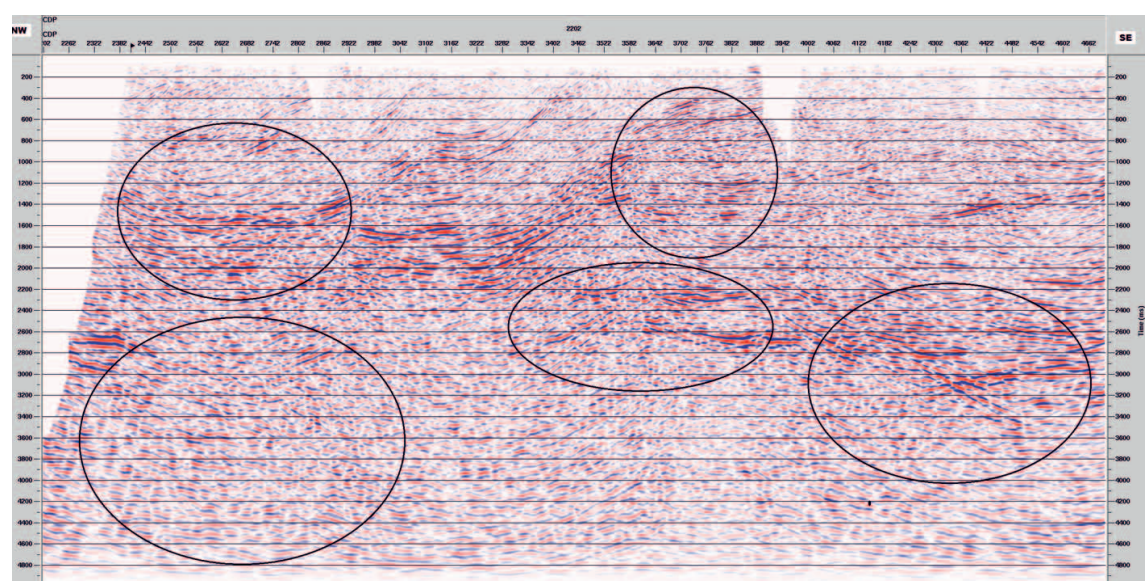

Rys. 11. Migracja czasowa wykonana algorytmem różnic skończonych dla pola prędkości interwałowych obliczonych algorytmem rozkładu Gaussa przy zastosowaniu $100 \%$ wartości pola prędkości

Fig. 11. Poststack time migration calculated with the Implicit FD Time Migration algorithm for the stacking velocity field performed with the Gauss algorithm using $100 \%$ of the velocity field value

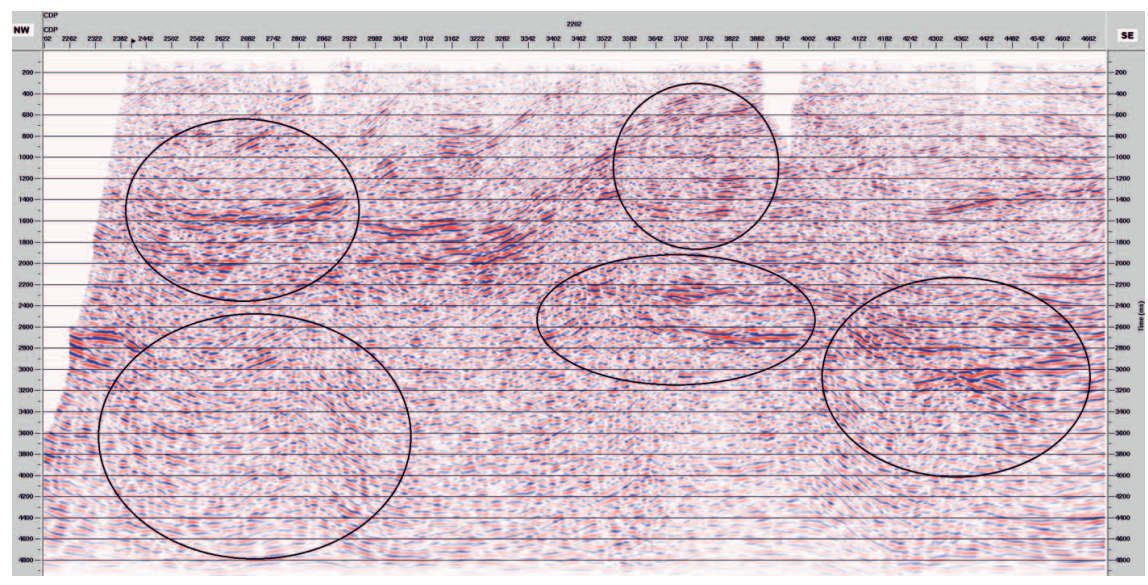

Rys. 12. Migracja czasowa wykonana algorytmem Stolta dla pola prędkości składania przy zastosowaniu $60 \%$ wartości pola prędkości

Fig. 12. Poststack time migration calculated with the Stolt algorithm for the stacking velocity field using $60 \%$ of the velocity field value 


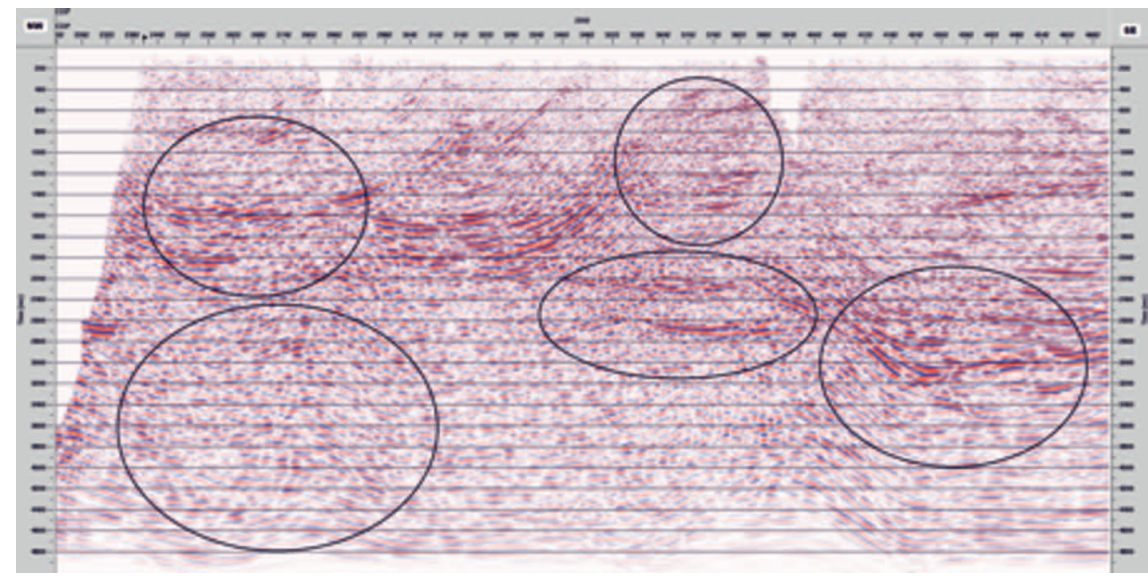

Rys. 13. Migracja czasowa wykonana algorytmem Stolta dla pola prędkości składania przy zastosowaniu $100 \%$ wartości pola prędkości

Fig. 13. Poststack time migration calculated with the Stolt algorithm for the stacking velocity field using $100 \%$ of the velocity field value

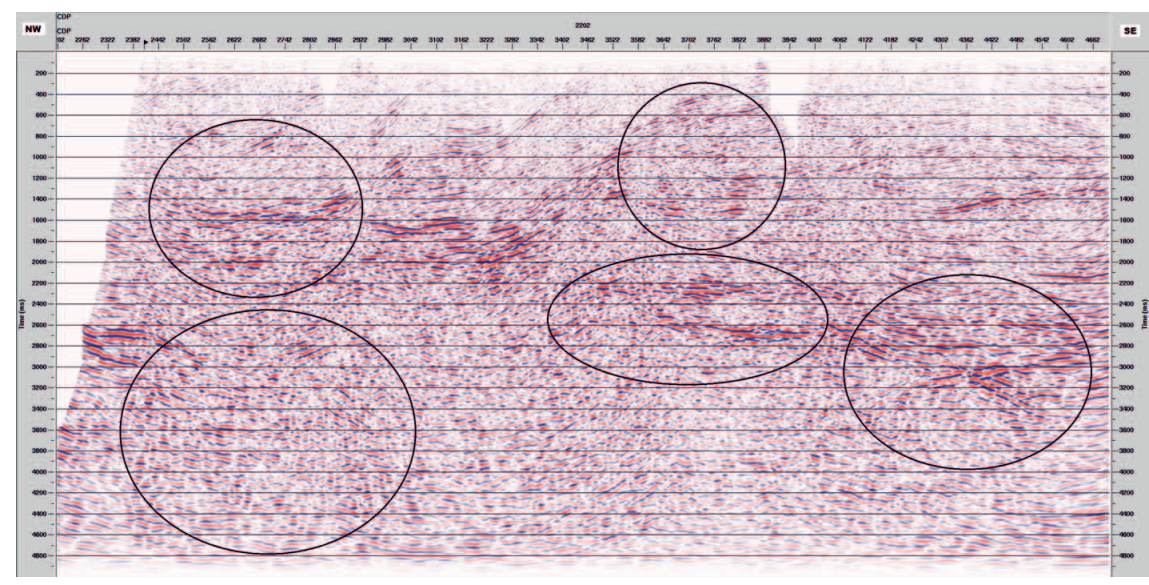

Rys. 14. Migracja czasowa wykonana algorytmem Kirchhoffa dla pola prędkości składania przy zastosowaniu $60 \%$ wartości pola prędkości

Fig. 14. Poststack time migration calculated with the Kirchhoff algorithm for the stacking velocity field using $60 \%$ of the velocity field value

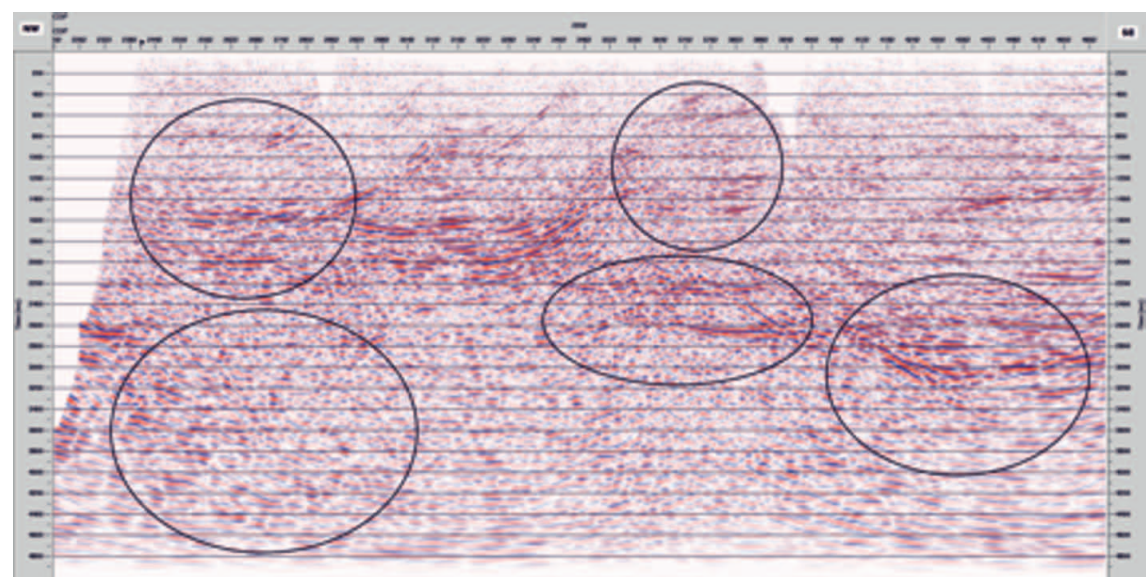

Rys. 15. Migracja czasowa wykonana algorytmem Kirchhoffa dla pola prędkości składania przy zastosowaniu $100 \%$ wartości pola prędkości

Fig. 15. Poststack time migration calculated with the Kirchhoff algorithm for the stacking velocity field using $100 \%$ of the velocity field value

czasowej po składaniu, otrzymano przy zastosowaniu algorytmu Implicit FD Time Migration (różnic skończonych) na podstawie modelu prędkości obliczonego rozkładem Gaussa przy zastosowaniu $60 \%$ wartości pola prędkości (rys. 10). Wspomniany obraz sejsmiczny charakteryzuje się najlepszą ciągłością i dynamiką refleksów oraz najmniejszą ilością szumów. Bardzo zbliżony obraz sejsmiczny uzyskano dla prędkości składania z wykorzystaniem algorytmu Stolta przy zastosowaniu $60 \%$ wartości pola prędkości (rys. 12). Jednak w przypadku migracji Stolta zauważa się większe zniekształcenie refleksów w podłożu jednostek fliszowych (tj. poniżej czasu $3200 \mathrm{~ms}$ ), podczas gdy ciągłość i dynamika refleksów sejsmicznych w niektórych miejscach wydaje się nawet lepsza niż po migracji przy użyciu algorytmu Gaussa (np. CDP 3882-4002, czas 2T 1000-1600 ms). Przy zastosowaniu wartości $100 \%$ pola prędkości (rys. 13) dla obu typów wyżej omawianych migracji w wielu strefach można zauważyć zwiększenie ciągłości i dynamiki refleksów w stosunku do wersji z użyciem $60 \%$ pola prędkości, jednak często obserwować można wyraźne „przemigrowania” refleksów.

\section{Podsumowanie i wnioski}

W artykule przedstawiono wyniki przetestowania kilku modeli prędkości na potrzeby migracji czasowej po składaniu. Trzy modele prędkości obliczone były na bazie prędkości interwałowych i interpretacji strukturalnej. Różnił je sposób interpolacji i ekstrapolacji w założonym gridzie obliczeniowym. Zastosowano trzy sposoby interpolacji i ekstrapolacji: według rozkładu Gaussa, kriging i moving average. Czwarty model prędkości skonstruowany został na bazie prędkości składania uzyskanych w procesie przetwarzania danych sejsmicznych. Pole prędkości obliczone na podstawie prędkości interwałowych i interpretacji strukturalnej zostało zastosowane do migracji czasowej po składaniu, wykonanej algorytmem Implicit FD Time Migration (różnic skończonych), natomiast pole prędkości składania zostało użyte do migracji czasowej po składaniu wykonanej algorytmami Stolta i Kirchhoffa. Dla potrzeb migracji w wybranych zakresach zastosowano trzy różne warianty prędkości, w zakresach procentowych $60 \%, 100 \%$ i $140 \%$. 
Najbardziej zadawalające wyniki dla wszystkich testowanych modeli uzyskano przy użyciu $60 \%$ procent pola prędkości. Na poszczególnych wariantach analizowanego profilu, otrzymanych w wyniku migracji czasowej dla różnych modeli prędkości, obraz strukturalny generalnie charakteryzuje się dużym podobieństwem, biorąc pod uwagę te same zakresy wartości procentowych użytego pola prędkości. Różnice można zauważyć przy bardziej szczegółowej analizie uzyskanych obrazów sejsmicznych, w których ujawniają się horyzontalne oraz wertykalne zmiany położenia refleksów sejsmicznych, różne kąty ich nachylenia (widoczne jest to szczególnie w zachodniej części analizowanego profilu), jak również zmiany w ich ciągłości i dynamice refleksów.

Najbardziej wiarygodny obraz sejsmiczny migracji czasowej po składaniu uzyskano dla pola prędkości obliczonego na bazie prędkości interwałowych z rozkładem Gaussa, przy użyciu algorytmu różnic skończonych dla migracji czasowej po składaniu i 60-procentowej wartości pola prędkości.

Pole prędkości do migracji czasowej po składaniu otrzymane na podstawie prędkości interwałowych z otworów wiertniczych i interpretacji strukturalnej może stanowić kolejną, niekiedy lepszą alternatywę w stosunku do prędkości składania.

Artykuł powstał na podstawie pracy statutowej pt. Porównanie modeli prędkości obliczonych z wykorzystaniem różnych wariantów prędkości i algorytmów na przykładzie danych geofizycznych z obszaru Karpat Zewnętrznych na potrzeby migracji czasowej po sktadaniu - praca INiG - PIB na zlecenie MNiSW; nr zlecenia: 0036/SR/2020, nr archiwalny: DK-4100-0024/2020.

\section{Literatura}

Al-Chalabi M., 1994. Seismic velocites - a critique. First Break, 12: 589-596.

Al-Chalabi M., Rosenkranz P., 2002. Velocity-depth and time-depth relationships for a decompacted uplifted unit. Geophysical Prospecting, 50: 661-664. DOI: 10.1046/j.1365-2478.2002.00345.x.

Bajewski Ł., Urbaniec A., Wilk A., Bartoń R., 2017. Poprawa dokładności odwzorowania budowy geologicznej w obrazie sejsmicznym z obszaru Karpat zewnetrznych. Nafta-Gaz, 7: 447-455. DOI:10.18668/NG.2017.07.01

Kasina Z., 2005. Interaktywne przetwarzanie danych sejsmicznych w systemie ProMAX. AGH Uczelniane Wydawnictwa NaukowoDydaktyczne, 1-95. ISBN 83-7464-013-8.

Kostecki A., 2011. Tilted Transverse Isotropy. Nafta-Gaz, 11: 769-776.

Kostecki A., Półchłopek A., 1998. Stable depth extrapolation of seismic wavefields by a Neumann series. Geophysics, 63(6): 2063-2071. DOI: $10.1190 / 1.1444499$.

Kostecki A., Półchłopek A., 2003. Prestack depth migration using converted waves. Acta Geophysica Polonica, 53(1): 73-84.

Kostecki A., Półchłopek A., 2013. Generalized migration in frequency - wavenumber domain $\mathrm{MG}(\mathrm{F}-\mathrm{K})$ in anizotropic media. Acta Geophysica, 61(3): 624-637. DOI: 10.2478/s11600-012-0098-5.

Kostecki A., Półchłopek A., Żuławiński K., 2013. Odwzorowanie struktur wgłębnych w ośrodkach anizotropowych metoda migracji sejsmicznej. Prace Naukowe Instytutu Nafty $i$ Gazu - Państwowego Instytutu Badawczego, 191: 1-134.
Kostecki A., Żuławiński K., 2013. Modeling of zero-offset time sections In TTI (Tilted Transverse Isotropy) media by pseudospectral method. Proc. EAGE Conference St. Petersburg.

Kostecki A., Żuławiński K., 2014. Modeling and migration of zero-offset time sections in TTI media by pseudo-spectral method. Nafta-Gaz, 12: 855-860.

Kostecki A., Żuławiński K., 2015. The pseudo-acoustic equations of the scalar wavefield in anisotropic media. Nafta-Gaz, 11: 811-815. 811-815. DOI: 10.18668/NG2015.11.01.

Kotlarczyk J., 1988. Geologia Karpat przemyskich - „szkic do portretu”. Przeglad Geologiczny, 36(6): 325-333.

Promax Reference Manual Contents, 2016. User Manual. <http://halliburton.com/landmark> (dostęp: 2020).

Schlumberger, 2020. The Oilfield Glossary. <http://www.glossary. oilfield.slb.com $>$ (dostep: listopad 2020).

Sheriff R., 2002. Encyclopedic Dictionary of Applied Geophysics. University of Houston.

Tsvankin I., Gaiser J., Grechka V., Van der Bann M., Thomsen L., 2010. Seismic anisotropy in exploration and reservoir characterization: An overview. Geophysics, 75(5): 75A15-75A29. DOI: $10.1190 / 1.3481775$

Urbaniec A., 2017. Nowe spojrzenie na budowę geologiczną brzeżnej części Karpat i ich podłoża (SE Polska) w oparciu o interpretację profili sejsmicznych 2D. Wiadomości Naftowe i Gazownicze: 20(2): 4-12.

Urbaniec A., Bajewski Ł., Wilk A., Bartoń R., 2017. Wstępna interpretacja strukturalna na bazie wyników reprocessingu profilu sejsmicznego 2D we wschodniej części Karpat zewnętrznych. Nafta-Gaz, 7: 456-464. DOI: 10.18668/NG.2017.07.02.

Wilk A., Bartoń R., Bajewski Ł., Urbaniec A., 2018. Budowa pola prędkości na potrzeby migracji czasowej 2D po składaniu w trudnych rejonach geologicznych na przykłądzie Karpat fliszowych w południowo-wschodniej Polsce. Nafta-Gaz, 10: 723-731. DOI 10.18668/NG.2018.10.03.

Yilmaz O., 2001. Seismic data analysis. Investigations in Geophysics No. 10, vol. I and II. Society of Exploration Geophysicist. ISBN 1560800941.

Żelaźniewicz A., Aleksandrowski P., Buła Z., Karnkowski P.H., Konon A., Oszczypko N., Ślączka A., Żaba J., Żytko K., 2011. Regionalizacja tektoniczna Polski. Komitet Nauk Geologicznych PAN, Wroctaw. ISBN 978-83-63377-01-4.

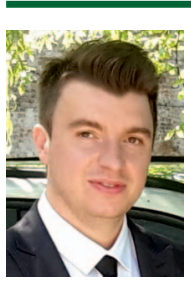

Mgr inż. Łukasz BAJEWSKI

Główny specjalista inżynieryjno-techniczny

w Zakładzie Sejsmiki

Instytut Nafty i Gazu - Państwowy Instytut Badawczy ul. Lubicz $25 \mathrm{~A}$

31-503 Kraków

E-mail: lukasz.bajewski@inig.pl

Mgr inż. Aleksander WILK
Główny specjalista inżynieryjno-techniczny
w Zakładzie Sejsmiki
Instytut Nafty i Gazu - Państwowy Instytut Badawczy
ul. Lubicz 25 A
31-503 Kraków
E-mail: wilka@inig.pl

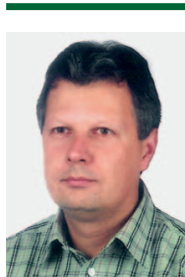

Dr Andrzej URBANIEC

Adiunkt; kierownik Zakładu Sejsmiki

Instytut Nafty i Gazu - Państwowy Instytut Badawczy ul. Lubicz $25 \mathrm{~A}$

31-503 Kraków

E-mail: andrzej.urbaniec@inig.pl 